\title{
REMARKS ON THE HEAD OF ROMAN SOLDIER IN THE GRAECO-ROMAN MUSEUM AT ALEXANDRIA
}

\author{
Abdel Basset A. ABDEL FATTAH \\ Lecturer, Faculty of Archaeology, Fayoum University, Egypt \\ E-mail: aaa40@fayoum.edu.eg
}

\begin{abstract}
This paper examines a head for a young warrior. It is kept in the Graeco-Roman Museum at Alexandria (Inv.No.3244). It is carved in white marble and measures $25 \mathrm{~cm}$. The dimension of the head indicates that once it belonged to a life size statue. The head is dressed in tightly strapped Attic helmet. The face is highly polished. His facial features indicate that it was dedicated to a young warrior. Breccia and Maehler suggested that this beautiful head representing a Roman soldier. This point of view is based on the helmet which was a military attribute. The head was dated to 180-190 A.D. Again, this suggestion is based on the similarity between our helmet and a helmet which is represented on a sarcophagus at the Louvre Museum (Ma.2119). This head owes much to the influence of the imperial sculpture of the Antonine age; especially the age of Commodus. It also reveals the influence of the classical sculptures of the fifth and fourth century B.C. This theory is reasonable, thought the Hellenic forms were common in the second century A.D.
\end{abstract}

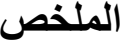

\section{KEYWORDS}

Roman art, Roman soldier, Attic Helmet, Crest block, Louvre sarcophagus, The portrait of Commdus, The portraits of the Antonine. 
This head belongs to a young warrior. It is kept at the Graeco-Roman Museum at Alexandria (Inv.No.3244). The head is made of white marble. It measures $25 \mathrm{~cm}$, which points to a life size statue. The head is dressed in tightly strapped Attic helmet. The face is softly treated and highly polished. The facial features indicate the young age which was the perfect age for the training of the Roman soldiers ${ }^{1}$. The forehead is triangular in outline, sunken in the middle, with protruding eyebrows, but does not show any wrinkles. The eyebrows are sharply carved, without indications of hairs. The eyes are lightly lidded, with cosmetic lines on the upper eyelid. The lower eyelid is softly depicted, merging into the cheek. The inner details of the almond shaped eyes are engraved. The circular pupil has another engraved hole for the iris. Both eyes are turned slightly upwards, with a slight turn to the left (fig.1). The broken nose appears to have a wide and long bridge; there are remains of using the drill in order to pattern the nostrils. The cheeks are very softly contoured, except the skin fold which is clearly indicated around the mouth. The mouth is small, and patterned in two rows. The lips are fleshy with sensual appearance. The chin is likewise small, and pointed (fig.2). The ears are slightly big, symmetrically rendered, visible out between the helmet and its chin strap. The earlobe seems to be damaged with the inner details summarily executed. (fig.3, a, b). The hair is neatly visible under the helmet, patterned in wavy long locks falling on both sides of the forehead ${ }^{2}$.

The Helmet is of the Attic type, which is known in different shapes and types during the Roman era $^{3}$.The Attic helmet is tightly fitting the head. The crescent is now missing, only remains of the crest block are kept. The remains on the helmet indicate a richly molded one. This type of elaborately decorated Attic helmets was common in the Roman period ${ }^{4}$. The bowl of the helmet is plain with triangular visor and protruding edge which gradually emerges into the helmet towards the sides. The chin strap is connected to the lower edge without details of its hanging technique; it is depicted in the form of a simple tape without decoration. It runs around the face before ears and throat. This type of legionary helmets, which continued to be tied with two straps under the chin, was common in the period between the late second century A.D. and the early third century A.D ${ }^{5}$.

Breccia and Maehler suggested that this beautiful head represents a Roman soldier. They noticed the great beauty and high technical and artistic quality. This suggestion was based on the helmet which was a military attribute for the Roman soldiers along the Roman age ${ }^{6}$. This head from Alexandria seems like the portraits from the sarcophagus of Ludovici (Rome, Roman National Museum.Palazzo Altemps, Inv.No.8574) from the mid-third century AD which depicted the Roman Militaries, who wore the same helmets. One of those portraits may depict a Roman commander, so the head from Alexandria with its decorated helmet may depict a Roman junior officer ${ }^{7}$ (fig.4). Some scholars date the head to late second century A.D. or the beginning of the third century A.D. ${ }^{8}$ However, the

\footnotetext{
${ }^{1}$ Le Bohec, Y., The Imperial Roman Army, p.119.

${ }^{2}$ Breccia, E. V., Alexandrea ad Aegyptum, p.176; Savvopoulos.K \& Bianchi.R.S., Alexandrian Sculpture in the Graeco-Roman Museum,p.36

${ }^{3}$ D'Amato, R\& Summer, G., Arms and Armour of the Imperial Roman Soldier from Marius to Commodus112 B.C- A.D.192, p.206.

${ }^{4}$ Lendon, J.E.L., Soldiers\& Ghost A History of Battle in Classical Antiquity, p.273.

${ }^{5}$ Adkins, L\& Adkins, R. A., Handbook to Life in Ancient Rome, p.88.

${ }^{6}$ Coulston, J.C.N, "How to Arm a Roman Soldier", in Austin, MN., Harries, JD. \& Smith, CJ. (eds.), Modus Operandi. How the Ancient World Worked. Papers Presented to Geoffrey Rickman; BICS supplementary, p.183; Maehler .,"Remarks on Some Sculptures in Alexandria", in BSAA 46, Alexandrian Studies II, in Honour of Mostafa El Abbadi ,Alexandria ,p.228 ;

${ }^{7}$ Ramage, N. . \& Ramage.A, Roman Art, p.250, pl.10.14. Kleiner.D. E. E., Roman Sculpture, p.389, pl.359.

${ }^{8}$ Savvopoulos, K \& Bianchi, R. S., Alexandrian Sculpture in the Graeco-Roman Museum, p.36.
} 
reasonable date is hundred eighty A.D. The similarity in the representation of our helmet and the helmet which is depicted on a sarcophagus at Louvre Museum (Ma.2119) (fig.5), points to this date. On the right side of the sarcophagus, there is a relief, depicting a battle between the Greek soldiers and the Amazons. The soldier to the left of the viewer, who grasps the Amazon from hair, is depicted with an Attic helmet, which seems very close to helmet of the head at Alexandria, especially its triangular visor, the crest block, and the hair locks which are visible under the helmet ${ }^{1}$. Furthermore the facial features of the Greek soldier look like those of our soldier in the softness, the highly polished skin, and the fleshy lips which are patterned in two rows. Technically, the full round pupil inside a circular iris indicates a late Antonine date.

This head owes much to the influence of imperial sculpture of the Antonine age, especially the reign of Commodus. The portraits of Commodus became idol for the private citizens, who followed the imperial fashion for their individuals ${ }^{2}$. The resemblance is clearly shown in the face of the bust of Commodus (the Kunsthistorisches Museum, Vienna, Marble, Inv.No.115) (fig.6) depicting the face of the emperor with the same features, the softness, the deep-set eyes, and the patterned lips. Breccia noticed the classical influence on our head $^{3}$. It seems plausible; the portraits of the Antonine emperors are descendants from the reigns of Trajan and Hadrian ${ }^{4}$. The two last emperors adopted the classical forms, especially of the sculptors of the fifth and fourth century B.C. ${ }^{5}$.In other words, from the reign of Trajan (96.A.D) to the death of Commodus (192.A.D.), the Hellenic forms and styles were common in the Roman art $^{6}$.

\section{CONCLUSION}

Dating of this sculptured head from the Graeco-Roman Museum of Alexandria based on technique and stylistic analysis can be estimated at around hundred eighty to hundred ninety A.D., which narrows down the commonly accepted broader dating. The helmet of the Attic type similar to the one known from another well-dated representation on the Louvre sarcophagus, and deeply carved pupils inside round irises are significant to determine the time of sculpture to late Antonine date. Furthermore, the helmet is important evidence to identify this young man as soldier, and many Roman sculptures depicting battle scene show similar helmets .

\footnotetext{
${ }^{1}$ Baratte \& Metzger, C.,Musée du Louvre, Catalogue des Sarcophagus en pierred époque romaine et paléochrétienne, p.259; Karapanagiotou, A.V.,"New Fragment of an Amazon Sarcophagus from Laconia", in BICS, p. 282.

${ }^{2}$ Strong, D., Roman Art, p.214.

${ }^{3}$ Breccia, E.V., "Alexandrea ad Aegyptum", in IIAG, p. 177.

${ }^{4}$ Tuck, S.L, A History of Roman Art, p.247.

${ }^{5}$ Ritcher.G.M.A., "Who Made the Roman Statues; Greeks or Romans?", in Proceeding of the APS, vol 95, No.29, p.191.

${ }^{6}$ Borg, B.E., A Companion to Roman Art, p.138.
} 


\section{LIST OF ABBREVIATIONS}

AMRC : Alexandrian and Mediterranean Research Center.

$A P S$ : American Philosophy Society.

$B A \quad$ : Bibliotheca Alexandrina.

$B I C S$ : Bulletin of the Institute of Classical Studies.

$B S A \quad$ : British School at Athens.

$B S A A$ : Bulletine de la Societie Archeologique d'Alexadrie.

$B S A S$ : British School at Athens Studies.

$I I A G \quad$ : Instituto Italiano d'Grafiche.

Ma : Marble.

\section{REFERENCES}

-Adkins, L. \& Adkins, R.A., Handbook to Life in Ancient Rome, Printed in U.S.A., (2004).

-Baratte, F\& Metzger, C., Musée du Louvre, Catalogue des Sarcophages en pierred époque romaine et paléochrétienne, Paris, (1985).

-Borg, E.B., A Companion to Roman Art, Willey Black welly \& sons.ltd, (2015).

-Breccia, E.V., Alexandrea ad Aegyptum, IIAG, Bergamo, (1922).

-Coulston, J.C.N., How to Arm a Roman Soldier, BICS, supplement.No.71, Wiely, London, (1998).

-D'Amato, R. \& Summer, G., Arms and Armour of the Imperial Roman Soldier from Marius to Commodus112 B.C-A.D.192, Frontline Books, London, (2009).

-Janson, H.W., Art of the Ancient World, Harry N. Abrams, New York, (1977).

-Karapanagiotou, A.V., 'New Fragment of an Amazon Sarcophagus from Laconia', BSAS.

Vol.16, (2009).

-Kleiner, D.E.E., Roman Sculpture, Yale University Press, (1922).

- Le Bohec,Y., The Imperial Roman Army, B.T.Batsford Ltd., London, (1994).

Lendon, J.E., Soldiers \& Ghost: A History of Battle in Classical Antiquity, Yale University Press, (2005).

-Maehler, H., 'Remarks on Some Sculptures in Alexandria', in BSAA 46, Alexandrian Studies II, in honour of Mostafa El Abbadi, Alexandria, (2000).

-Ramage, N.H. \& Ramage, A., Roman Art, Prentic Hall, Inc.,New Jersey, (1991).

-Ritcher, G.M.A., 'Who Made the Roman Statues; Greeks or Romans?', in Proceeding of the APS., Vol.95, No.29 (April.30.1951), published by APS, (1951)

-Savvopoulos, K. \& Bianchi, R.S., Alexandrian Sculpture in the Graeco-Roman Museum, Series1, AMRC., BA., (2012).

- Strong, D., Roman Art, Penguin books, London, (1976).

-Tuck, S.L, a History of Roman Art, Wiley Blackwell, U.K., (2005). 


\section{Plates}

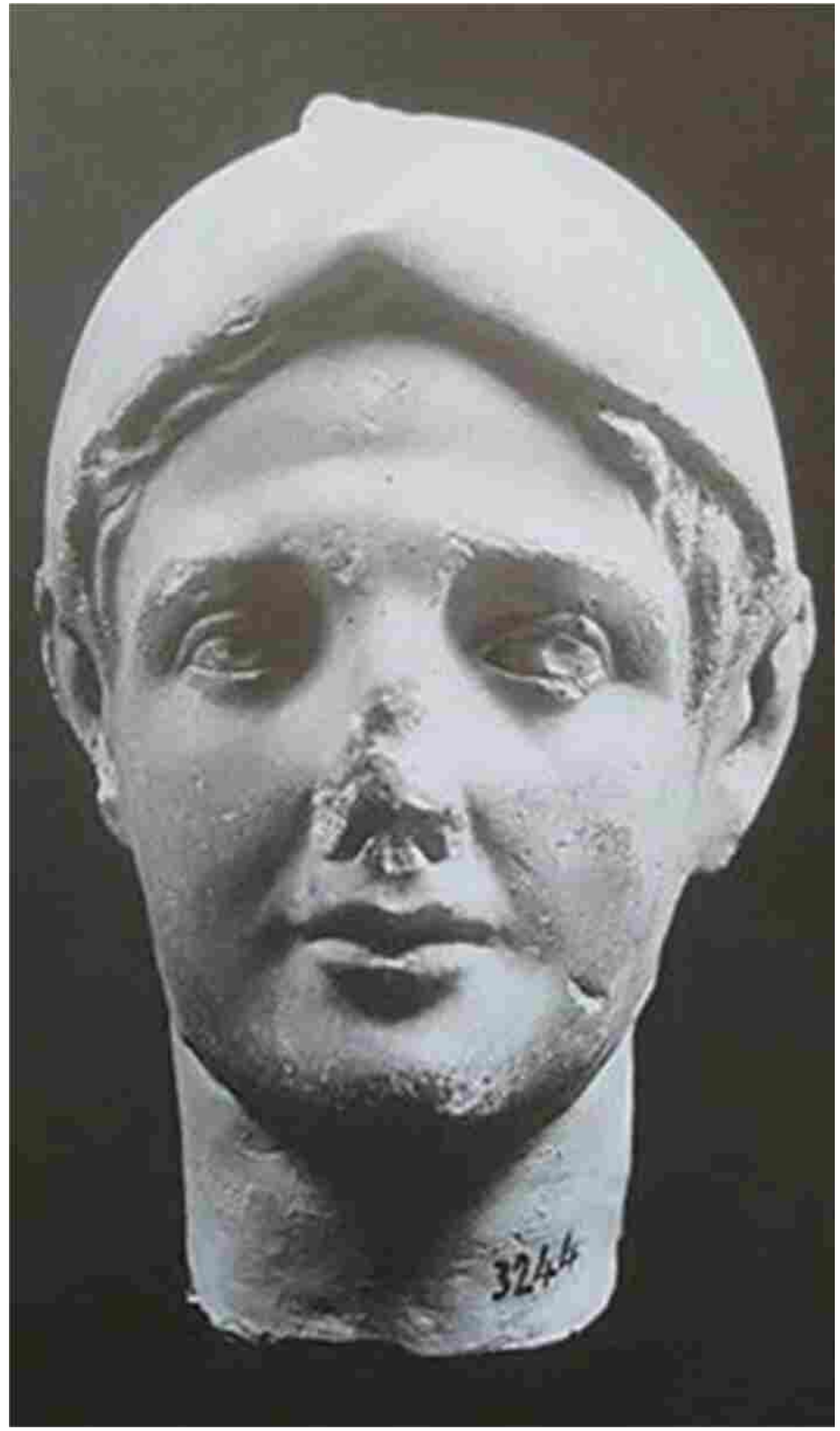

Fig.1: The head of the soldier, front view after Savvopoulos, K. pl.4 


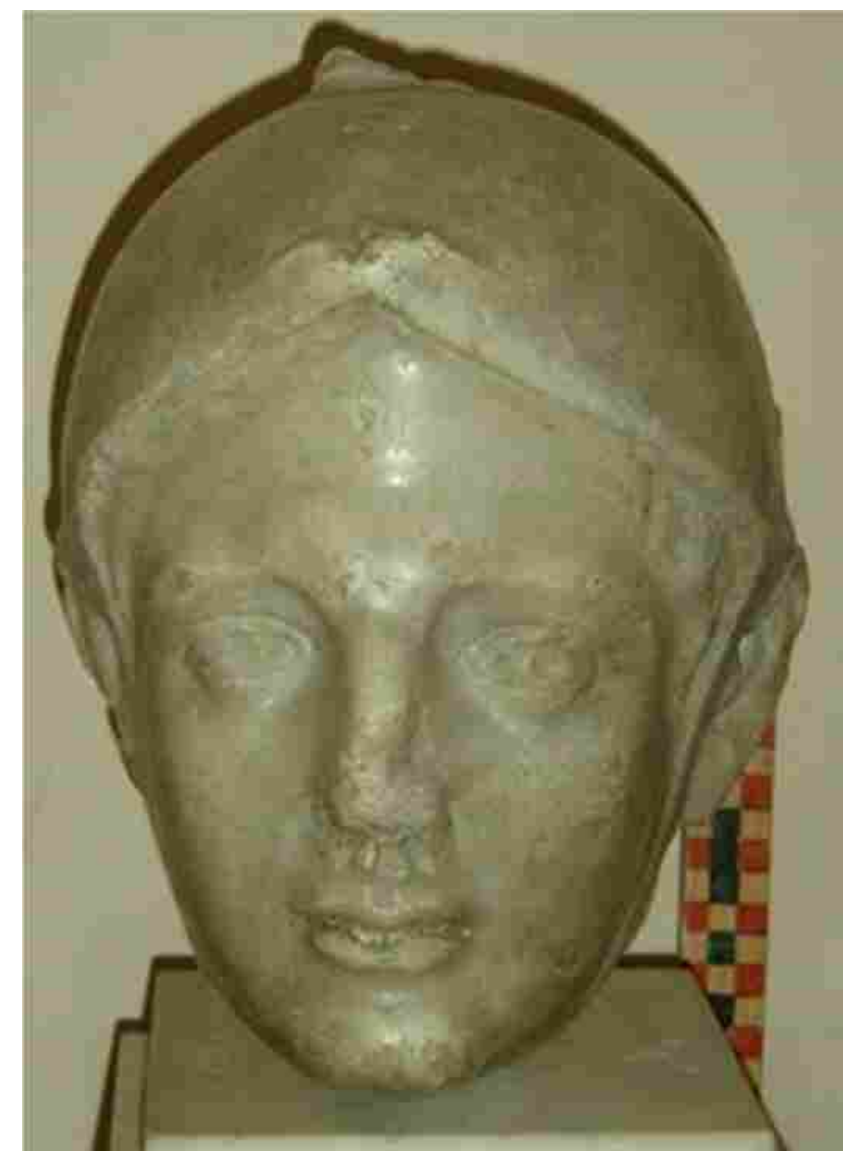

Fig.2: The head of the Roman soldier, front view, courtesy of Sobhi Ashour
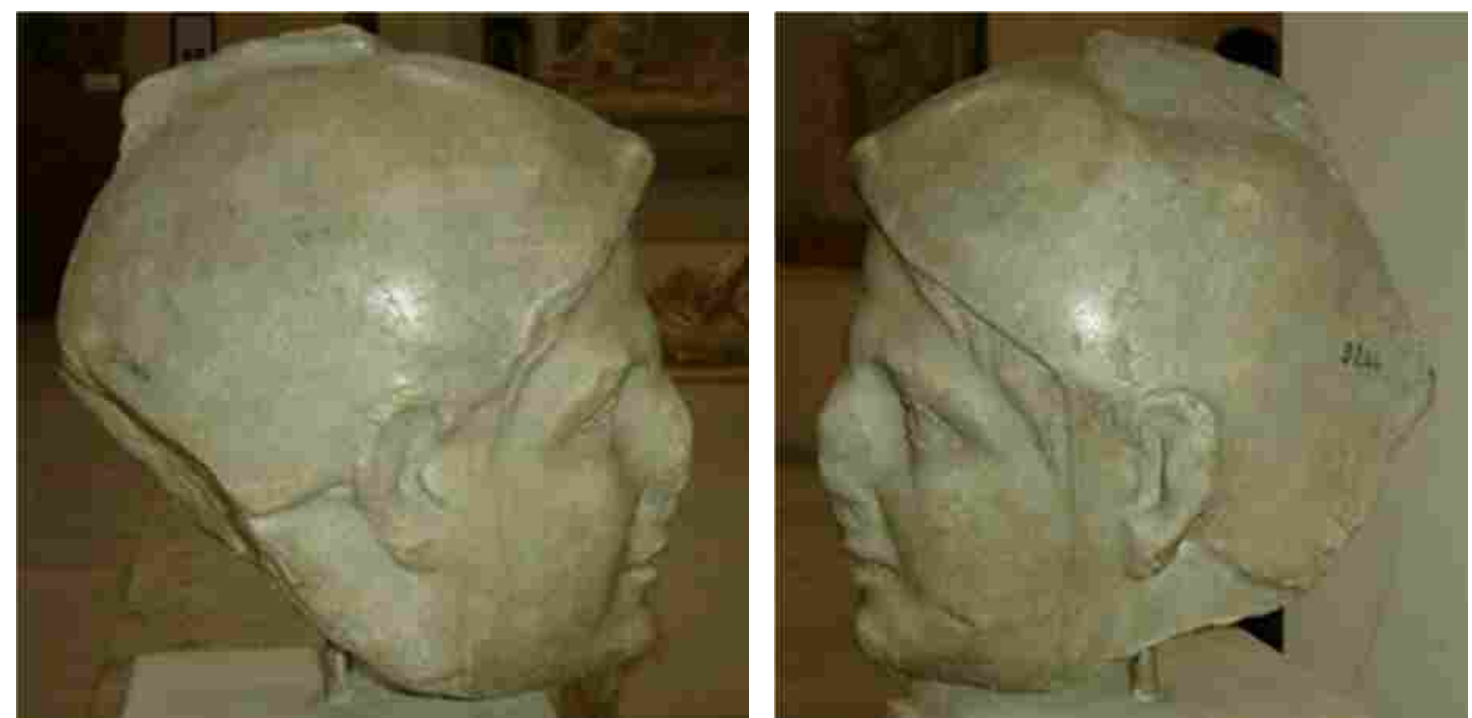

Fig.3, a \&b: The head of the Roman soldier, a: view from right side, b: view from left side, courtesy of Sobhi Ashour 


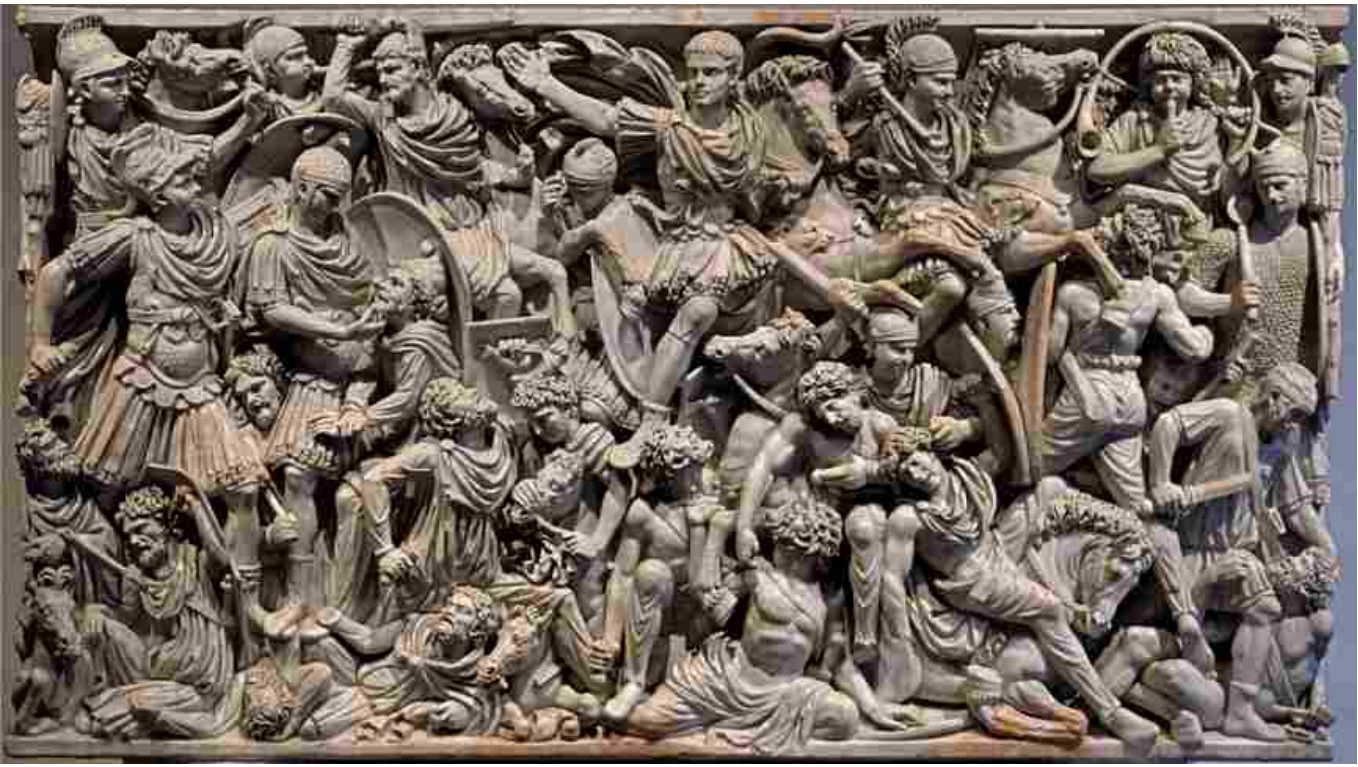

Fig.4: The sarcophagus with battle scene known as the Great Ludovici sarcophagus, Rome, Roman National Museum, Palazzo Altemps Inv.No.8574, 250 A. Ancientrome.ru/art/artworken/img.htm? $=6597$ (Assecced on 28/9/2018 5:44:35 pm).

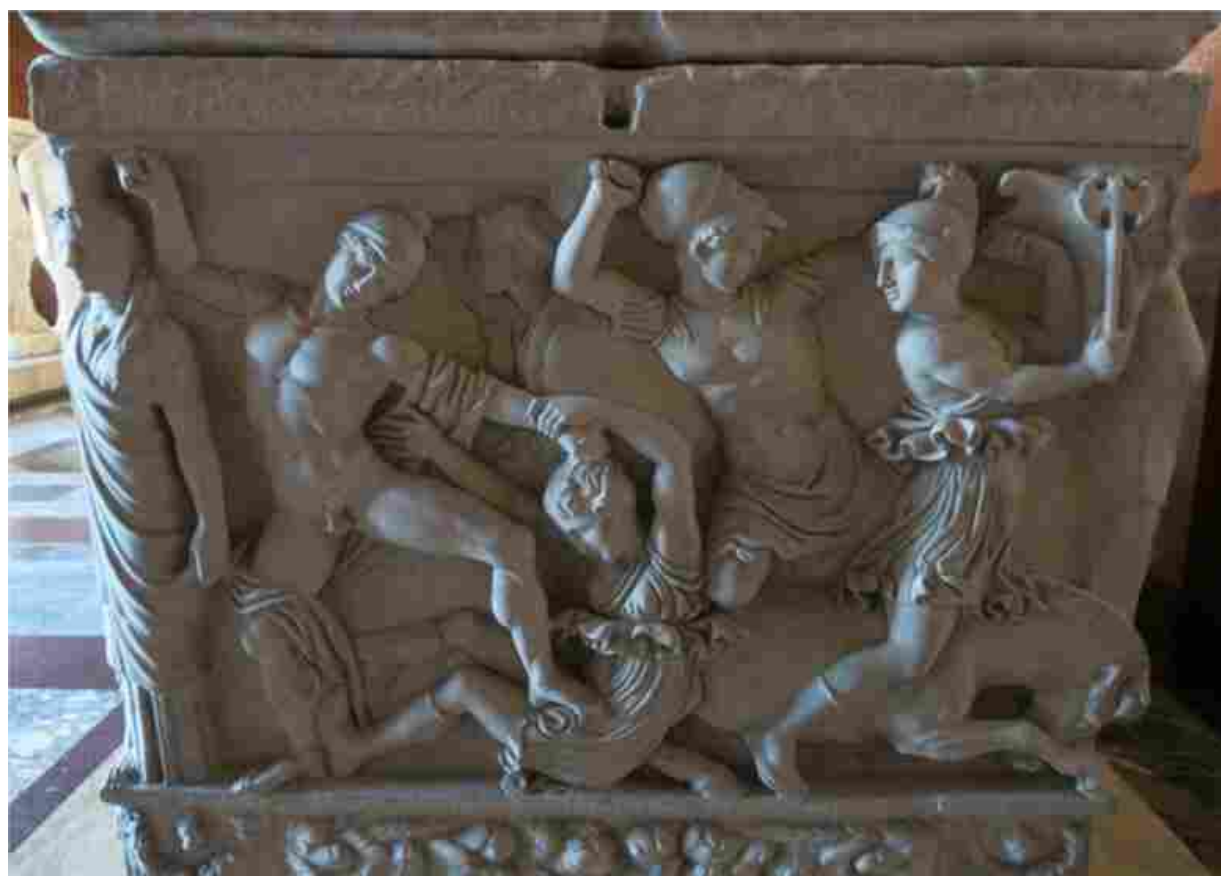

Fig.5: AmazonomachySarcophagus, Louvre Museum, Ma.2119, 180 A.D.

http://commons.wikimedia/wiki/File:Amazonomachy_sarcophagus_(Louvre,_Ma_211 9)_side.JPG (Assecced on 3/9/2017 12:33:07 pm) 


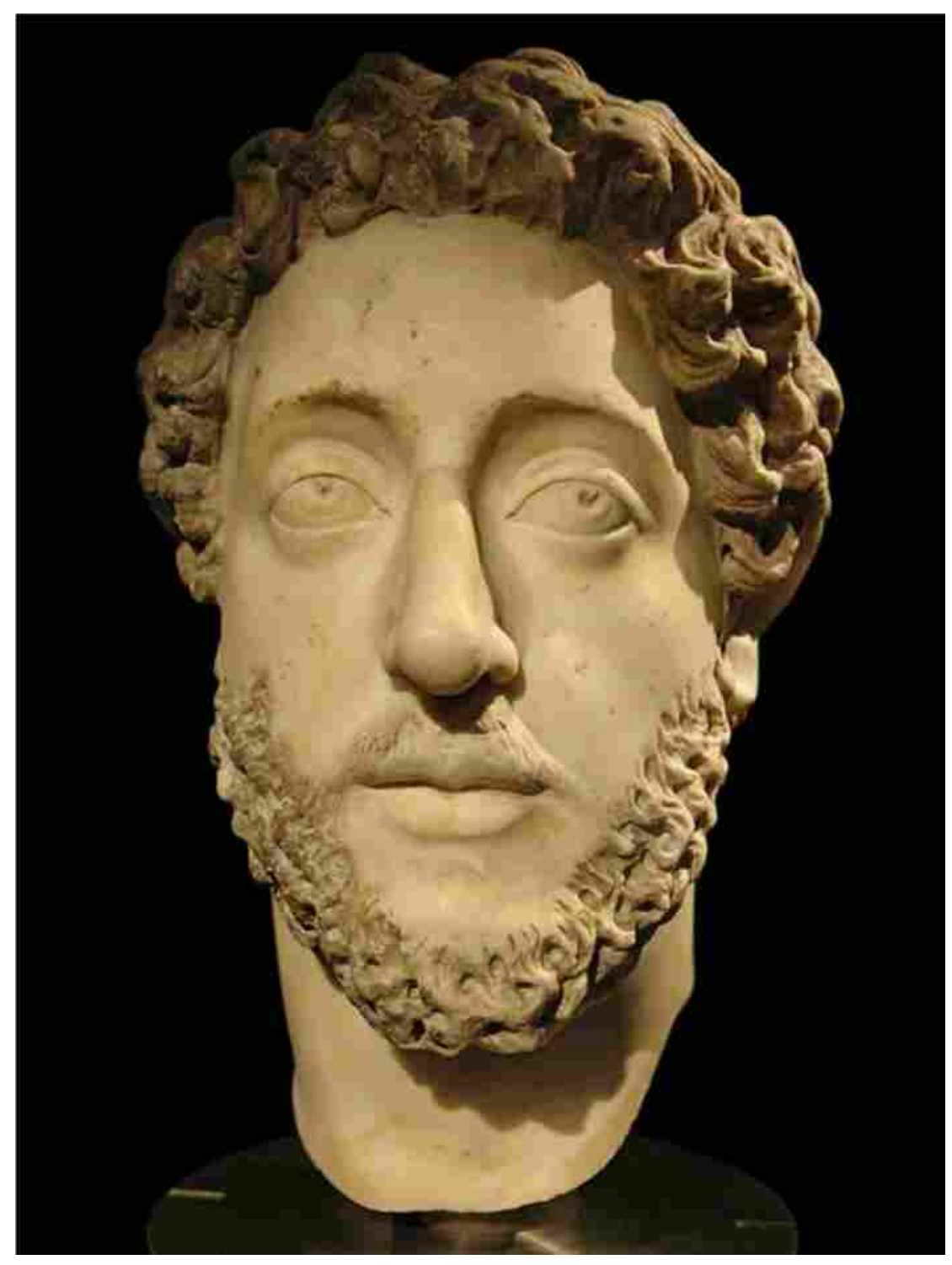

Fig.6: the portrait of Commodus, the Kunsthistorisches Museum, Vienna, Marble, Inv.No.115 (accessed on 26/9/2018 9:57) 